\title{
KAJIAN KUAT TEKAN DAN INFILTRASI PADA BETON NON PASIR (Study Of Compressive Strength And Infiltration Of no-fines Concrete)
}

\author{
Edi Kurniadi ${ }^{1}$, Lava Himawan ${ }^{2}$ \\ ${ }^{1}$ Program Diploma Teknik Sipil/Departemen Teknik Sipil/Sekolah Vokasi UGM \\ Email: ${ }^{1}$ edikur2005@gmail.com \\ ${ }^{2}$ Program Diploma Teknik Sipil/Departemen Teknik Sipil/Sekolah Vokasi UGM \\ Email: ${ }^{2}$ lava_himawan@ugm.ac.id
}

\begin{abstract}
No fines concrete can be known such as porous concrete, no-fines concrete and pervious concrete, because not use of sand in the mixture causing the cavities between coarse aggregates. When the rainy season, especially in urban areas there are many flood because the water is difficult to infiltration into the ground. Because permeable nature of non-fines concrete which can accelerate the absorption of water to the soil and to the water channel, reduce run-off and increase groundwater reserves. In this research will study for compressive strength and infiltration in non-finnes concrete. This research uses coarse aggregates from the results of stone crushing machines with coarse aggregate sizes (5-10) mm. cement: aggregate ratio used $1: 2 ; 1: 3 ; 1: 4 ; 1: 5 ; 1: 6 ; 1: 7$; 1: 8. The study began with material checking, planning of material requirements, making non-sand concrete, then testing compressive strength, and infiltration testing at the age of 28 days. The results showed that the compressive strength of non-finnes concrete with a variation of the ratio of cement : gravel 1: 2 is 33.19 MPa while for a mixture of 1: 8 it is $5.23 \mathrm{MPa}$. The Infiltration rate has increased along with the greater variation in the ratio of the mixture. The maximum infiltration rate for a mixture of $1: 8$ is $9.44 \mathrm{~mm} / \mathrm{sec}$. The infiltration rates in no-finnes concrete can be used to accelerate the absorption of water into the soil and can function to reduce water on the surface of the yard.
\end{abstract}

Keywords: No-finnes concrete, compressive strength, infiltration

\begin{abstract}
ABSTRAK
Beton non pasir dikenal dengan istilah beton porous, no-fines concrete dan pervious concrete, karena tidak menggunakan pasir dalam campuran menyebabkan rongga antar agregat kasar. Ketika musim hujan terutama di kawasan perkotaan banyak terdapat genangan air karena air sulit meresap ke dalam tanah. Karena sifatnya yang permeable maka beton non pasir dapat mempercepat penyerapan air ke tanah maupun ke saluran air, mengurangi run-off dan menambah cadangan air tanah. Penelitian ini bertujuan untuk menguji kuat tekan dan kemampuan infiltrasi beton non-pasir. Penelitian beton non-pasir ini menggunakan agregat kasar dari hasil mesin pemecah batu dengan ukuran agregat kasar (5-10)mm, rasio semen:agregat yang digunakan 1:2; 1:3; 1:4; 1:5; 1:6; 1:7; $1: 8$. Penelitian diawali dengan pemeriksaan bahan, perencanaan kebutuhan bahan, pembuatan beton non-pasir kemudian dilakukan pengujian kuat tekan dan pengujian infiltrasi. Hasil menunjukkan bahwa kuat tekan beton non pasir dengan variasi perbandingan campuran semen kerikil 1:2 sebesar 33,19 MPa sedangkan untuk campuran $1: 8$ sebesar 5,23 MPa. Laju infiltrasi beton non pasir mengalami peningkatan seiring dengan semakin besar variasi perbandingan campuran. Laju infiltrasi paling besar terjadi pada campuran 1:8 sebesar 9,44 mm/det. Laju infiltrasi yang besar pada beton non pasir dapat digunakan untuk mempercepat penyerapan air ke dalam tanah dan dapat berfungsi untuk mengurangi genangan air di permukaan halaman.
\end{abstract}

Kata kunci:. Beton non pasir, kuat tekan, infiltrasi

\section{PENDAhuluan}

Indonesia memiliki curah hujan yang tinggi. Ketika musim hujan terutama di kawasan perkotaan banyak ditemukan genangan air yang menyebabkan kualitas lingkungan menurun. Genangan air tersebut biasanya terjadi pada daerah permukiman penduduk dan jalan-jalan. Persoalan genangan air ini menimbulkan dampak negatif yang tidak bisa diabaikan karena menyangkut kerugian dan penderitaan yang bersifat non fisik maupun fisik, sebagai contoh adalah dampak genangan air terhadap sarana infrastruktur kota, sebagian besar ruas-ruas jalan yang tergenang air mengalami kerusakan parah, sehingga menggangu aktivitas lalu lintas di ruas jalan tersebut. Keadaan yang seperti ini memerlukan upaya penanganan yang tepat, ditambah lagi persoalan genangan suatu persoalan teknis dan non teknis. Cara untuk mengurangi genangan air di permukaan jalan yaitu menggunakan beton non pasir yang memiliki sifat porus. Karena sifat permeable beton non pasir yang dapat mempercepat penyerapan air ke tanah maupun ke saluran air sehingga dapat mengurangi genangan air. 
Beton non pasir atau no-fines concrete adalah bentuk sederhana dari beton ringan yag dibuat dengan cara mengurangi penggunaan agregat halus atau dengan tidak menggunakan pasir dalam campuran menyebabkan terciptanya rongga antar agregat kasar, rongga dalam campuran merata dan saling terkoreksi (kadar rongga berkisar antara $12 \%-25 \%$ ). Kelebihan utama dari beton non-pasir ini adalah dapat meredam panas, proses pembuatannya yang cepat, kepadatnya yang rendah, porositasnya tinggi, sifat penyusutan yang rendah, mudah meloloskan air. Kepadatan beton non-pasir tergantung pada gradasi agregat kasar yang digunakan. Agregat batu pecah menghasilkan kuat tekan yang lebih tinggi dibanding jika meggunakan kerikil alami yang memiliki permukaan bulat. Beton non pasir telah banyak digunakan. Umumnya diaplikasikan sebagai area parkir, jalur jalan dengan lalu lintas ringan, trotoar serta permukiman yang berwawasan lingkungan karena sifatnya yang permeable (dapat meloloskan air). Penelitian ini mengkaji kuat tekan dan laju infiltrasi pada beton non pasir. Bahan yang digunakan untuk penelitian adalah kerikil dari sungai Krasak, Sleman Yogyakarta kemudian di pecah dengan mesin stone crusher dengan ukuran butiran agregat $5 \mathrm{~mm}$ sampai $10 \mathrm{~mm}$.

Beton non-pasir memiliki berat jenis yang rendah jika dibandingakan dengan beton normal. Berat jenis beton non pasir diperngaruhi oleh berat jenis dan gradasi aggregat penyusunnya. Berat jenis beton non pasir dengan menggunakan aggregat batu apung berkisar 1,60 (sulistyowati ,2000).

Hasil penelitian nenunjukan beton non pasir dengan agregat batu pada nilai fas 0,40 , memberikan nilai zero slump karena airnya bayank yang terserap agregat, namun dengan demikian tidak berarti bahwa beton non pasir tidak dapat dikerjakan. Rasio volume semen - agregat pada campuran beton non pasir 1:6 sebesar 7,67 MPa dengan kebutuhan semen per $\mathrm{m}^{3}$ sebanyak $285,41 \mathrm{~kg}$. (Trisnoyuwono,2009).

Dalam penelitian beton non-pasir ini menggunakan agregat kasar dari hasil mesin pemecah batu dengan ukuran agregat kasar (5-10)mm. rasio semen:agregat yang digunakan $1: 2 ; 1: 3 ; 1: 4 ; 1: 5 ; 1: 6 ; 1: 7 ; 1: 8$. Penelitian dimulai dengan pemeriksaan bahan, perencanaan kebutuhan bahan, pembuatan beton non-pasir, kemudian dilakukan pengujian kuat tekan, dan pengujian infiltrasi pada umur 28 hari.

Beton non-pasir dapat dikenal dengan berbagai istilah seperti beton porous, no-fines concrete, permeconcrete dan pervious concrete, dengan tidak digunakannya pasir dalam campuran menyebabkan terciptanya rongga antar agregat kasar, distribusi rongga dalam campuran merata dan saling terkoneksi (kadar rongga berkisar antara $12 \%$ $25 \%$ ) menyebabkan berkurangnya kepadatan beton dan permukaan efektif butiran yang harus diselimuti oleh pasta semen. Kelebihan utama dari beton non-pasir ini adalah dapat merendam panas, proses pembuatannya yang cepat, kepadatan yang rendah, porositasnya yang tinggi, sifat penyusutan yang rendah dan mudah meloloskan air.

Kepadatan beton non-pasir tergantung pada gradasi agregat kasar yang digunakan, pada umumnya kepadatannya berkisar antara 60\%-75\% dari beton normal. Ukuran agregat yang biasa digunakan 5-10mm 10-20 mm, meskipun ukuran yang lebih besar masih juga dapat digunakan. Beberapa jenis agregat seperti batu pecah, kerikil alami, blast furnace slag (hasil sampingan dalam pegolahan logam dalam tanur tegak) dan clinker (dari bahan tanah liat yang dibakar-batu bekah) dapat menjadi bahan penyusun beton non pasir. Agregat batu pecah menghasilkan kuat tekan yang lebih tinggi dibanding jika menggunakan kerikil alami yang cendrung memiliki permukaan rounded (Raju, 1983).

Pada umumnya beton non pasir memiliki berat jenis yang rendah jika dibandingkan dengan beton normal. Berat jenis beton non pasir dipengaruhi oleh berat jenis dan gradasi aggregat penyusunnya. Beton non pasir juga mempunyai kelemahan seperti berikut :

a) Porus yaitu beton non pasir tidak direkomendasikan dengan baja tulangan apalagi jika berada pada lingkungan yang agresif, sifatnya yang porus dapat mempercepat laju korosi pada baja tulangan.

b) Kuat tekan rendah karena rongga-ronnga yang kosong tidak dapat memikul tegangan. Jadi tegangan hanya dipikul pada daerah koneksi antar agregat yang diikat dengan pasta semen.

Beton akan mengalami pengerasan setelah setting time terlampaui sehingga dengan bertambahnya waktu maka akan mempunyai kuat tekan yang berbeda, berdasarkan SNI untuk pengujian beton didasarkan pada umur 28 hari. Perbandingan kuat tekan beton untuk umur tertentu dapat dilihat pada Tabel 1.1:

Tabel 1. Perbandingan kuat tekan beton

\begin{tabular}{llllllll}
\hline \multicolumn{2}{l}{ Perbandingan Kekuatan Tekan Beton Pada Berbagai Umur } \\
\hline Umur beton ( hari ) & 3 & 7 & 14 & 21 & 28 & 90 & 365 \\
Semen Portland ( biasa ) & 0,40 & 0,65 & 0,88 & 0,95 & 1,00 & 1,20 & 1,35 \\
\hline *Sumber PBI 1971 & \multicolumn{1}{l}{ Sum }
\end{tabular}


Sifat pada beton yang menonjol adalah kuat tekannya, maka dari itu dalam pembuatan beton sifat ini yang ditergetkan. Ukuran benda uji kuat tekan menurut SNI adalah berupa silinder beton dengan ukuran Diameter 150 $\mathrm{mm}$ dan tinggi $300 \mathrm{~mm}$.

Menurut Asdak (2010), ketika air hujan jatuh ke permukaan tanah atau lapisan permukaan, sebagian air tertahan di cekungan-cekungan, sebagian air mengalir sebagai limpasan(run off) dan sebagian lainnya meresap kedalam tanah. Saat hujan mencapai permukaan lahan maka akan terdapat bagian hujan yang mengisi ruang kosong (void) dalam tanah yang terisi udara (soil moisture deficiency) sampai mencapai kapasitas lapang (field capacity) dan berikutnya bergerak ke bawah secara gravitasi akibat berat sendiri dan bergerak terus kebawah (perkolasi) kedalam daerah jenuh (saturated zone) yang terdapat di bawah permukaan air tanah (phreatik). Air yang berada pada lapisan air tanah jenuh dapat pula bergerak ke segala arah (ke samping dan ke atas) dengan gaya kapiler atau dengan bantuan penyerapan oleh tanaman melalui tudung akar.

Proses masuknya air dari atas (surface) ke dalam tanah disebut infiltrasi. Sedangkan laju infiltrasi (ft) adalah infiltrasi maksimum yang ditentukan oleh kondisi permukaan termasuk lapisan atas dari tanah. Perkolasi merupakan proses kelanjutan perjalanan air tersebut ke tanah yang lebih dalam. Dengan kata lain, infiltrasi adalah perjalanan air ke dalam tanah sebagai akibat gaya kapiler (gerakan air ke arah lateral) dan gravitasi (gerakan air ke arah vertikal).

Setelah keadaan jenuh pada lapisan tanah bagian atas terlampaui, sebagian dari air tersebut mengalir ke tanah yang lebih dalam sebagai akibat gaya gravitasi bumi dan dikenal sebagai proses perkolasi. Besarnya laju infiltrasi atau perkolasi dinyatakan dalam $\mathrm{mm} / \mathrm{jam}$ atau $\mathrm{mm} / \mathrm{hari}$.

Pengukuran laju perkolasi bisa dilakukan dengan ring infiltrometer yang biasa digunakan adalah infiltrometer ganda (double ring infiltrometer), yaitu satu infiltrometer silinder ditempatkan di dalam infiltrometer silinder lain yang lebih besar. Infiltrometer silinder yang lebih kecil mempunyai ukuran diameter sekitar $30 \mathrm{~cm}$ dan infiltrometer yang besar mempunyai diameter 46 hingga $50 \mathrm{~cm}$, panjang infiltrometer sekitar $60 \mathrm{~cm}$. Pengukuran hanya dilakukan pada silinder yang kecil. Silinder yang lebih besar hanya berfungsi sebagai penyangga yang bersifat menurunkan efek batas yang timbul oleh adanya silinder (Asdak,1995).

Nilai laju infiltrasi berbanding lurus dengan jumlah rongga antara ikatan-ikatan agregat pada beton lolos air. Semakin banyak jumlah rongga maka semakin besar pula nilai laju infiltrasinya, sebaliknya semakin sedikit jumlah rongganya maka semakin kecil pula nilai laju infiltrasinya. Nilai laju infiltrasi dalam satuan $\mathrm{mm} / \mathrm{jam}$ dengan menggunanakan infiltration ring yang berdiameter $300 \mathrm{~mm}$ dan metode pengujiannya berdasarkan acuan pada ASTM C 1701/C 1701 M-09. Dihitung dengan rumus:

$I=\frac{K M}{D^{2} t}$

Dimana :

$\mathrm{I}=$ laju infiltrasi, $\mathrm{mm} / \mathrm{jam}$

$\mathrm{M}=$ berat air, $\mathrm{kg}$

$\mathrm{D}=$ diameter dalam, $\mathrm{mm}$

$\mathrm{t}=$ waktu, detik

$\mathrm{K}=$ konstanta, 4583666000

Kuat tekan beton merupakan hasil bagi dari beban maksimum dengan luas penampang benda uji. Benda uji diukur sisi-sisinya untuk mengetahui luas permukaan tekannya, kemudian diletakkan pada mesin tekan. Tekanan diberi secara merata dan terus menerus sampai bahan maksimum. Hasil dari pembacaan dial di analisa dengan persamaan sebagai berikut :

Kuat tekan $\left(\mathrm{f}^{\prime} \mathrm{c}\right)=\mathrm{P} / \mathrm{A}\left(\mathrm{N} / \mathrm{mm}^{2}\right)$

Dengan:

$\mathrm{P}=$ Beban tekan maksimum, $(\mathrm{N})$

$\mathrm{A}=$ Luas bidang tekan, $\left(\mathrm{mm}^{2}\right)$ 


\section{BAHAN DAN METODE PENELITIAN}

\section{Bahan}

Bahan yang digunakan adalah berupa semen portland gresik, kerikil ukuran 5-10 mm, air , bahan tambah kimia.

\section{Alat}

Alat uji kerikil, Alat uji tekan, Alat uji infiltrasi.

\section{Metode/Prosedur penelitian}

1)Tahap persiapan

2)Tahap pemeriksaan bahan

3)Tahap Perhitungan Campuran adukanbeton non-pasir

4)Tahap Pencampuran Adukan beton non-pasir

5)Tahap pembuatan benda uji

Benda uji yang di pakai berupa silinder beton diameter $150 \mathrm{~mm}$ dan tinggi 300mm digunakan untuk pengujian kuat tekan. Benda uji berupa plat beton ukuran $400 \mathrm{~mm}$ x $400 \mathrm{~mm}$ x $150 \mathrm{~mm}$ digunakan untuk pengujian infiltrasi. Pengujian kuat tekan dilakukan terhadap benda uji setelah 7,14 dan 28 hari. Sedangkan pengujian infiltrasi dilakukan pada umur 28 hari.

\section{HASIL DAN PEMBAHASAN}

\section{Agregat}

Hasil pengujian terhadap agregat kerikil ukuran 5-10 mm pada penelitian ini meliputi berat satuan, kandungan lumpur, dan berat jenis, los angeles. Hasil-hasil pengujian tersebut seperti pada Tabel 2.

Tabel 2. Hasil Pengujian Agregat Kerikil

\begin{tabular}{cccc}
\hline Jenis Pengujian & Hasil Pengujian & Standar & Kesimpulan \\
\hline Berat Satuan & 1,21 ton $/ \mathrm{m}^{3}$ & $1,2-1,8$ & Agregat ringan \\
Berat Jenis kerikil & 2,44 & $2,2-2,9$ & Memenuhi syarat \\
( Merapi Sungai Krasak) & & & Memenuhi syarat \\
Kandungan lumpur & 0.7 & $1 \%$ & Memenuhi syarat \\
Los Angeles & $48.5 \%$ & $50 \%$ &
\end{tabular}

Berdasarkan hasil pengujian pemeriksaan kerikil yang digunakan memenuhi syarat sebagai bahan untuk membuat beton.

\section{Kebutuhan bahan}

Kebutuhan bahan adukan beton non pasir berdasarkan variasi campuran untuk tiap meter kubik beton non pasir dapat dilihat pada Tabel 3 .

Tabel 3. Kebutuhan bahan beton non pasir

\begin{tabular}{|c|c|c|c|c|c|c|c|}
\hline $\begin{array}{l}\text { Rasio perbandingan berat } \\
\text { semen - kerikil }\end{array}$ & $1: 2$ & $1: 3$ & $1: 4$ & $1: 5$ & $1: 6$ & $1: 7$ & $1: 8$ \\
\hline FAS & & & & 0.4 & & & \\
\hline Jenis semen Portland & & & & TIPE & & & \\
\hline Berat satuan agregat $\left(\mathrm{kg} / \mathrm{m}^{3}\right)$ & 1800 & 1800 & 1800 & 1800 & 1800 & 1800 & 1800 \\
\hline $\begin{array}{l}\text { Kebutuhan agregat } \\
\text { per } \mathrm{m}^{3} \text { beton }(\mathrm{kg})\end{array}$ & 1800 & 1800 & 1800 & 1800 & 1800 & 1800 & 1800 \\
\hline Kebutuhan semen per $\mathrm{m}^{3}$ beton $(\mathrm{kg})$ & 900 & 600 & 450 & 360 & 300 & 257.14 & 225 \\
\hline Kebutuhan air per $\mathrm{m}^{3}$ beton $(\mathrm{kg})$ & 360 & 240 & 180 & 144 & 120 & 102.86 & 90 \\
\hline $\begin{array}{l}\text { Kebutuhan damdex } \\
\text { per } \mathrm{m}^{3} \text { beton }(\mathrm{kg})\end{array}$ & 18 & 12 & 9 & 7.2 & 6 & 5.2 & 4.5 \\
\hline $\begin{array}{l}\text { Berat beton non pasir } \\
\text { per } \mathrm{m}^{3} \text { beton }(\mathrm{kg})\end{array}$ & 3078 & 2652 & 2439 & 2311.2 & 2226 & 2165.2 & 2119.5 \\
\hline
\end{tabular}

\section{Kuat tekan beton non pasir}

Hasil pengujian kuat tekan beton non pasir untuk beberapa variasi perbandingan campuran pada umur 28 hari dapat dilihat pada Tabel 4. dan Gambar 1. 
Tabel 4. Kuat tekan beton non pasir umur 28 hari

\begin{tabular}{|c|c|c|c|c|}
\hline \multirow{2}{*}{ No } & \multirow{2}{*}{ Variasi campuran } & \multicolumn{3}{|c|}{ umur 28 hari } \\
\hline & & Beban $(\mathrm{kN})$ & fc' ( $\mathrm{MPa})$ & rata2 fc' ( $\mathrm{MPa})$ \\
\hline \multirow[t]{3}{*}{1} & $1: 2$ & 601.4 & 34.03 & 33.19 \\
\hline & & 595.7 & 33.71 & \\
\hline & & 562.7 & 31.84 & \\
\hline \multirow[t]{3}{*}{2} & $1: 3$ & 499.5 & 28.27 & 27.32 \\
\hline & & 480 & 27.16 & \\
\hline & & 468.8 & 26.53 & \\
\hline \multirow[t]{3}{*}{3} & $1: 4$ & 399.8 & 22.62 & 22.61 \\
\hline & & 410.9 & 23.25 & \\
\hline & & 387.9 & 21.95 & \\
\hline \multirow[t]{3}{*}{4} & $1: 5$ & 310.4 & 17.57 & 16.91 \\
\hline & & 296.6 & 16.78 & \\
\hline & & 289.7 & 16.39 & \\
\hline \multirow[t]{3}{*}{5} & $1: 6$ & 135.7 & 7.68 & 8.51 \\
\hline & & 138.3 & 7.83 & \\
\hline & & 177.2 & 10.03 & \\
\hline \multirow[t]{3}{*}{6} & $1: 7$ & 142.2 & 8.05 & 6.84 \\
\hline & & 111.8 & 6.33 & \\
\hline & & 108.8 & 6.16 & \\
\hline \multirow[t]{3}{*}{7} & $1: 8$ & 101.5 & 5.74 & 5.23 \\
\hline & & 91.5 & 5.18 & \\
\hline & & 84.1 & 4.76 & \\
\hline
\end{tabular}



Gambar 1. Grafik kuat tekan beton non pasir umur 28 hari

Hasil pengujian kuat tekan beton non pasir untuk beberapa variasi perbandingan campuran pada umur 7, 14 dan 28 hari dapat dilihat pada Tabel 5 dan Gambar 2.

Tabel 5. Kuat tekan beton non pasir umur 28 hari

\begin{tabular}{ccccc}
\hline \multirow{2}{*}{ No } & $\begin{array}{c}\text { Perbandingan } \\
\text { Campuran }\end{array}$ & umur 7 hari & rata2 Kuat Tekan f'c (MPa) \\
\cline { 3 - 5 } & $1: 2$ & 21.34 & 29.39 & umur 28 hari \\
\hline 1 & $1: 3$ & 17.67 & 23.70 & 33.19 \\
2 & $1: 4$ & 14.59 & 19.86 & 27.32 \\
3 & $1: 5$ & 10.73 & 14.64 & 22.61 \\
4 & $1: 6$ & 5.48 & 7.48 & 16.91 \\
5 & $1: 7$ & 4.26 & 6.02 & 8.51 \\
6 & $1: 8$ & 3.37 & 4.59 & 6.84 \\
7 & & & & 5.23 \\
\hline
\end{tabular}




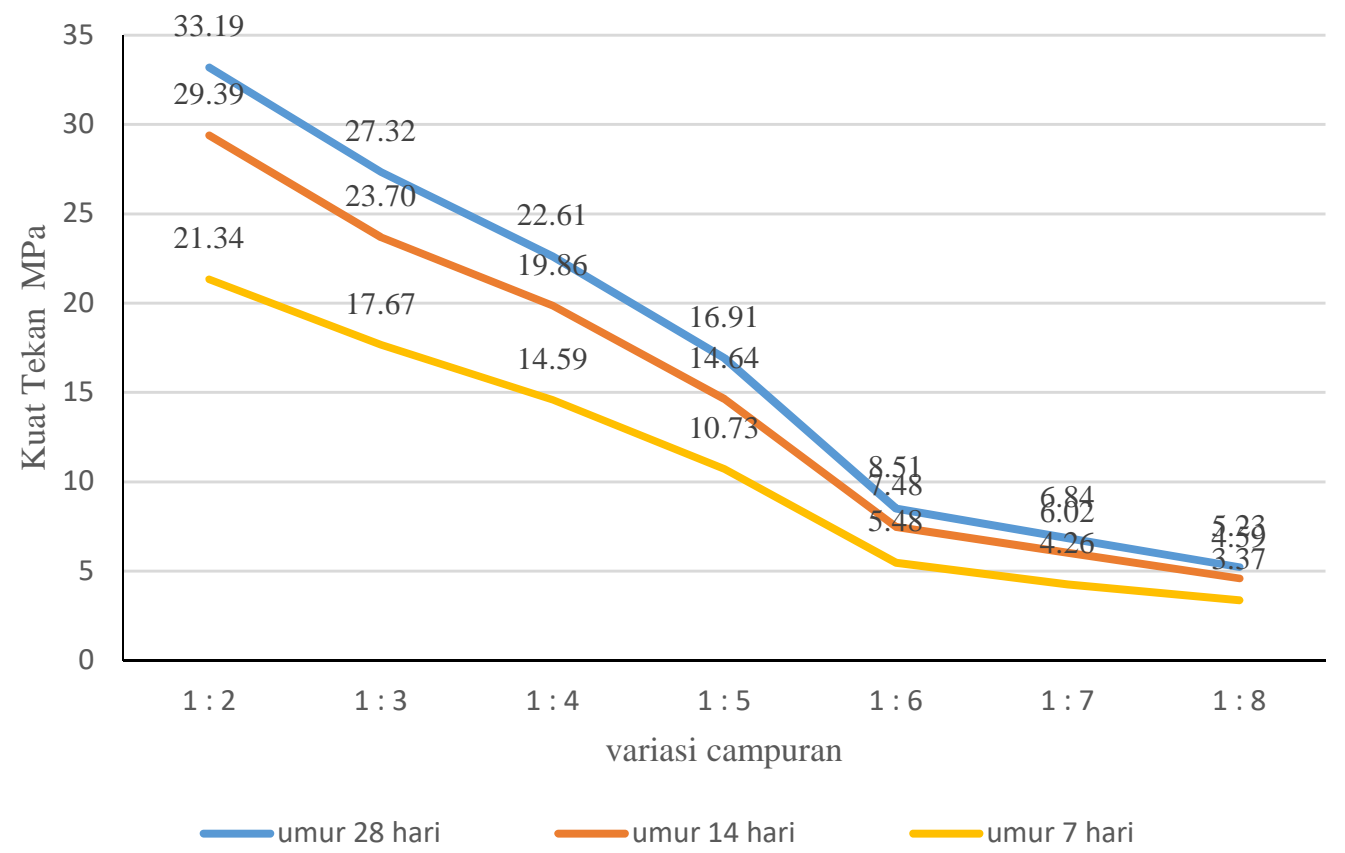

Gambar 2. Grafik kuat tekan beton non pasir umur 7, 14 dan 28 hari.

Gambar 1 dan Gambar 2 menunjukkan bahwa kuat tekan beton non pasir mengalami peningkatan seiring mengecilnya variasi perbandingan campuran semen dan kerikil. Hal ini disebabkan semakin kecil variasi perbandingan semen dan kerikil semakin banyak jumlah semen yang digunakan. Kuat tekan beton non pasir semakin meningkat seiring bertambahnya umur beton hal ini disebabkan proses hidrasi semen semakin lama semakin semakin kuat. Kuat tekan terbesar umur 28 hari didapatkan pada campuran $1: 2$ sebesar 33,19 MPa dan kuat tekan terkecil pada campuran 1:8 sebesar 5,23 MPa.

\section{Laju Infiltrasi}

Hasil pengujian laju infiltrasi beton non pasir untuk beberapa variasi perbandingan semen kerikil pada umur 28 hari dapat dilihat pada Tabel 6 dan Gambar 3.

Tabel 6. Laju infiltrasi beton non pasir umur 28 hari

\begin{tabular}{|c|c|c|c|c|c|c|c|}
\hline No & $\begin{array}{l}\text { Campuran } \\
\text { PC:Kerikil }\end{array}$ & $\begin{array}{c}\text { Diameter } \\
\mathrm{D}(\mathrm{mm})\end{array}$ & $\begin{array}{c}\text { Berat Air } \\
\text { M (kg) }\end{array}$ & $\begin{array}{l}\text { Waktu } \\
\mathrm{t} \text { (detik) }\end{array}$ & $\begin{array}{l}\text { Laju Infiltrasi } \\
\text { I (mm/jam) }\end{array}$ & $\begin{array}{c}\text { Laju Infiltrasi } \\
\text { I (mm/det) }\end{array}$ & $\begin{array}{c}\text { Rata rata } \\
\mathrm{I}(\mathrm{mm} / \mathrm{det})\end{array}$ \\
\hline 1 & & 300 & 20 & 120.33 & 8464.99 & 2.35 & \\
\hline 2 & $1: 2$ & 300 & 20 & 115.62 & 8809.83 & 2.45 & 2.46 \\
\hline 3 & & 300 & 20 & 110.17 & 9245.64 & 2.57 & \\
\hline 4 & & 300 & 20 & 78.56 & 12965.79 & 3.60 & \\
\hline 5 & $1: 3$ & 300 & 20 & 80.17 & 12705.41 & 3.53 & 3.68 \\
\hline 6 & & 300 & 20 & 72.48 & 14053.43 & 3.90 & \\
\hline 7 & & 300 & 20 & 56.85 & 17917.19 & 4.98 & \\
\hline 8 & $1: 4$ & 300 & 20 & 50.45 & 20190.14 & 5.61 & 5.59 \\
\hline 9 & & 300 & 20 & 45.73 & 22274.05 & 6.19 & \\
\hline 10 & & 300 & 20 & 43.12 & 23622.27 & 6.56 & \\
\hline 11 & $1: 5$ & 300 & 20 & 36.77 & 27701.73 & 7.69 & 7.25 \\
\hline 12 & & 300 & 20 & 37.69 & 27025.54 & 7.51 & \\
\hline 13 & & 300 & 20 & 49.10 & 20745.26 & 5.76 & \\
\hline 14 & $1: 6$ & 300 & 20 & 35.47 & 28717.01 & 7.98 & 6.95 \\
\hline 15 & & 300 & 20 & 39.79 & 25599.21 & 7.11 & \\
\hline 16 & & 300 & 20 & 38.33 & 26574.29 & 7.38 & \\
\hline 17 & $1: 7$ & 300 & 20 & 39.31 & 25911.79 & 7.20 & 7.42 \\
\hline 18 & & 300 & 20 & 36.90 & 27604.13 & 7.67 & \\
\hline 19 & & 300 & 20 & 33.53 & 30378.54 & 8.44 & \\
\hline 20 & $1: 8$ & 300 & 20 & 31.23 & 32615.83 & 9.06 & 9.44 \\
\hline 21 & & 300 & 20 & 26.18 & 38907.27 & 10.81 & \\
\hline
\end{tabular}




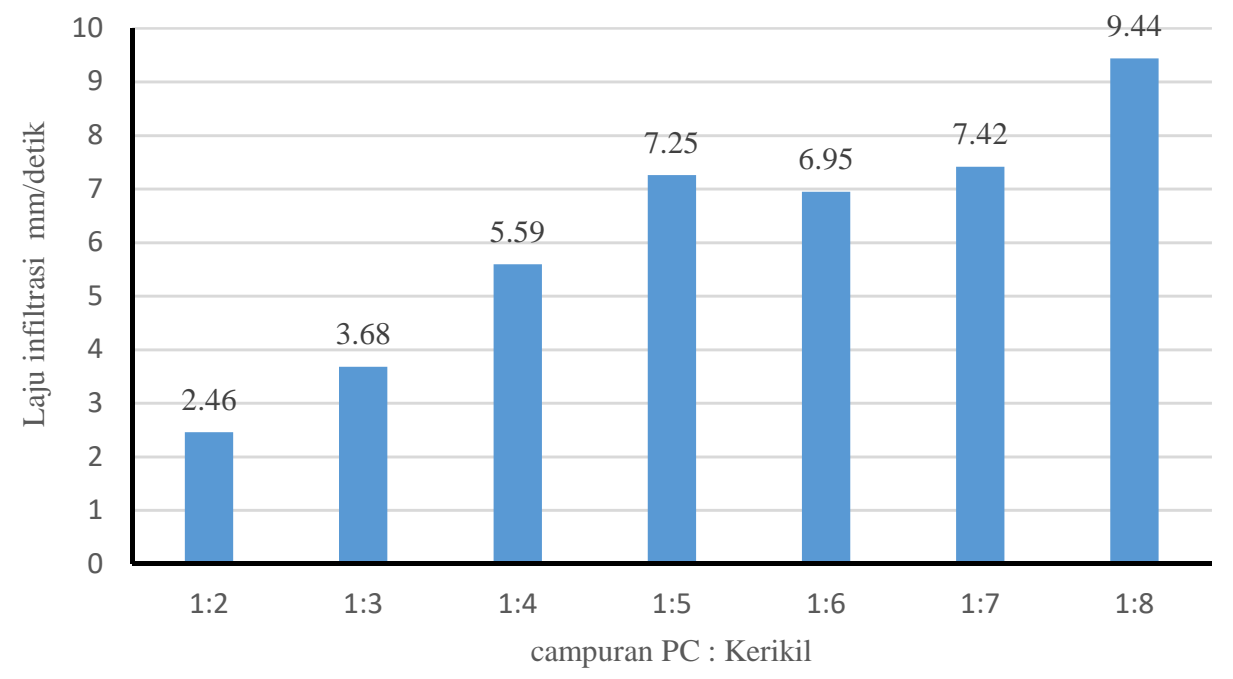

Gambar 3. Grafik laju infiltrasi beton non pasir umur 28 hari

Dari gambar 3 menunjukkan bahwa semakin besar variasi perbandingan campuran semen dan kerikil maka semakin besar laju infiltrasi hal ini disebabkan karena semakin besar perbandingan semen dan kerikil menyebabkan semakin sedikit pasta semen sehingga semakin berongga atau porus. Laju infiltrasi terbesar pada variasi campuran 1: 8 dengan laju infiltrasi sebesar 9,44 mm/det sedangkan laju infiltrasi terkecil pada variasi perbandingan campuran $1: 2$ sebesar $2,46 \mathrm{~mm} / \mathrm{det}$.

\section{KESIMPULAN}

Dari hasil kajian beton non pasir dengan beberapa variasi perbandingan campuran dapat diambil beberapa kesimpulan sebagai berikut:

1 Kuat tekan beton non pasir dengan variasi perbandingan campuran semen kerikil $1: 2$ sebesar 33,19 $\mathrm{MPa}$ sedangkan untuk campuran 1:8 sebesar 5,23 MPa.

2 Kuat tekan beton non pasir campuran 1:2 sampai 1: 4 mempunyai kuat tekan lebih besar dari 17,5 MPa termasuk dalam beton struktural, sedangkan untuk campuran $1: 5$ sampai $1: 8$ termasuk beton non struktural.

3 Laju infiltrasi beton non pasir mengalami peningkatan seiring dengan semakin besar variasi perbandingan campuran semen kerikil. Laju infiltrasi untuk campuran 1:8 sebesar 9,44 mm/det. Laju infiltrasi yang besar pada beton non pasir dapat digunakan sebagai media untuk mempercepat penyerapan air ke dalam tanah dan dapat berfungsi untuk mengurangi genangan air di permukaan halaman.

\section{UCAPAN TERIMA KASIH}

Terimakasih kami ucapkan kepada kepala laboratorium bahan bangunan dan laboratorium struktur Departemen Teknik Sipil SV UGM, teknisi, laboran yang telah memberikan bantuan kelancaran penelitian ini. Kepada mahasiswa bimbingan tugas akhir yang telah membantu pelaksanaan penelitian.

\section{DAFTAR PUSTAKA}

American Society For Testing And Materials, 1992, Annual Book of ASTM Standard, Philadelphia, USA. Asdak, C. 2010, Hidrologi dan Pengelolaan Daerah Aliran Sungai, Gadjah Mada University Press. Darwis, Z, 2017, Beton non pasir dengan penggunaan agregat local dari merak, Jurnal Fondasi, Volume 6 DPU, 1982, Persyaratan Umum Bahan Bangunan Indonesia, Departemen Pekerjaan Umum, Bandung Mindess Sidney dan Young L. Francis, 1981, Concrete, Prentice Hall, New jersey. Mulyono, Tri 2005, Teknologi Beton, Andi, Yogyakarta

Raju, Krisna N, 1983, Design of Concrete Mixes, CBS Publishers \& Distributors, Jain Bhawan, Bhola Nath Nagar, Shandra, Delhi India

Sulistyowati ,2000, Pemanfaatan Breksi Batu Apung ukuran 5mm - 20mm Sebagai Agregat Beton Non-Pasir. Tugas Akhir. Jurusan Teknik Sipil, Universitas Gadjah Mada, Yogyakarta.

Tjokrodimuljo, K. 2007. Teknologi Beton. Edisi Pertama,Teknik Sipil Universitas Gadjah Mada. Yogyakarta. Trisnoyuwono, 2009, Beton non pasir dengan agregat dari batu alam sungai lua kabupaten kepulauan talaud Sulawesi utara, Forum Teknik Sipil no. XIX 